\title{
IMPLEMENTASI PENDEKATAN PEMBELAJARAN BERBASIS AKTIVITAS SISWA UNTUK MELATIH KETERAMPILAN BERPIKIR KREATIF DAN PENGUASAAN KONSEP
}

\author{
Danang Ricco Setyo Nugroho ${ }^{1}$, Muslimin Ibrahim², Yuni Sri Rahayu ${ }^{3}$ \\ ${ }^{1}$ Mahasiswa Program Pascasarjana, Prodi Pendidikan Dasar, Universitas Negeri Surabaya, \\ ${ }^{2 \& 3}$ Dosen Pascasarjana, Prodi Pendidikan Dasar, Universitas Negeri Surabaya \\ e-mail: 1danangricco@gmail.com
}

\section{Received : Juli 2018}

Reviewed: Agustus 2018

Accepted : September 2018

Published : September 2018
ABSTRACT

This study aimed to describe the implementation of activities based learning to facilitate students' creative thinking skills and mastery of concepts. Samples were fifth grade students at SDN Babat Jerawat II Surabaya and fifth grade students at SDN Rangkah VII Surabaya. The topic used in this study is Human Organs and Animals. Research conducted the academic year 2016/2017. This type of research is quasi experiment. The research design was pretest-posttest control group design. The instrument used in this study include: 1) observation sheet implementation of learning; 2) student activity observation sheet; 3) creative skills test instruments; and 4) the test instrument mastery of concepts. Data analysis technique using inferential analysis to determine the differences in the test results of creative thinking skills and mastery of concepts between the experimental group and the control group using $t$ test analysis. Based on the results of t-test results obtained significance value of 0.000 $<0.05$ for creative thinking skills tests. As for the concept mastery test results obtained significance value of $0.020<0.05$. From the test results of $t$-tests, we can conclude that there are significant differences between creative thinking skills and mastery of concepts in the control group (instead of activities based learning) and experiment group (activities based learning).

Keywords: Concept Mastery, Creative Thinking Skills, Students Activities Based Learning.

\section{ABSTRAK}

Penelitian ini bertujuan untuk mendeskripsikan implementasian pendekatan pembelajaran berbasis aktivitas siswa untuk melatih keterampilan berpikir kreatif dan penguasaan konsep. Sampel penelitian ini adalah siswa kelas V di SDN Babat Jerawat II Surabaya dan siswa kelas V di SDN Rangkah VII Surabaya. Adapun materi yang digunakan dalam penelitian ini adalah Tema Organ Tubuh Manusia dan Hewan. Penelitian dilaksanakan tahun ajaran 2016/2017. Jenis penelitian yang digunakan adalah eksperimen semu. Desain penelitian yang digunakan adalah Pretest-Posttest Control Group Design. Instrumen yang digunakan dalam penelitian ini meliputi: 1) lembar pengamatan pelaksanaan pembelajaran; 2) lembar pengamatan aktivitas siswa; 3) instrumen tes keterampilan kreatif; dan 4) instrumen tes penguasaan konsep. Adapun teknik analisis data menggunakan analisis inferensial untuk mengetahui adanya perbedaan hasil tes keterampilan berpikir kreatif dan penguasaan konsep antara kelompok eksperimen dan kelompok kontrol menggunakan analisis uji t-tes. Berdasarkan hasil uji t-tes diperoleh hasil nilai signifikansi sebesar $0,000<0,05$ untuk tes keterampilan berpikir kreatif, sedangkan untuk tes penguasaan konsep diperoleh hasil nilai signifikansi sebesar $0,020<0,05$. Dari hasil uji t-tes tersebut dapat disimpulkan bahwa terdapat perbedaan yang signifikan antara keterampilan berpikir kreatif dan penguasaan konsep pada kelompok kontrol (pendekatan pembelajaran bukan berbasis aktivitas siswa) dan kelompok eksperimen (pendekatan pembelajaran berbasis aktivitas siswa).

Kata Kunci: Keterampilan Berpikir Kreatif, Pembelajaran Berbasis Aktivitas Siswa, Penguasaan Konsep 


\section{PENDAHULUAN}

Dari studi pendahuluan yang dilakukan peneliti mendapatkan temuan yang menggolongkan pembelajaran di SDN Babat Jerawat II Surabaya dan SDN Rangkah VII Surabaya masih memposisikan guru sebagai satu-satunya sumber belajar, yaitu (1) guru langsung menyampaikan tujuan pembelajaran, (2) guru kemudian menyajikan informasi tentang materi yang diajarkan, (3) guru meminta anak-anak untuk mengerjakan soal yang ada di buku, (4) guru membahas soal yang telah dikerjakan, dan (5) guru menyimpulkan secara bersama-sama.

Dikedua sekolah tersebut, peneliti juga diperoleh data bahwa kemampuan berpikir kreatif siswa masih cukup rendah. Dari delapan puluh siswa yang mengikuti tes dengan skala penilaian 1-100 hanya terdapat dua belas siswa yang masuk dalam kategori berpikir kreatif tinggi dengan interval nilai 75-100, lima belas siswa masuk kategori sedang dengan interval nilai 50-75, sisanya sejumlah 53 siswa masuk dalam kategori rendah dengan interval nilai adalah 20-50. Untuk penguasaan konsep siswa, dari delapan puluh siswa yang mengikuti tes hanya terdapat tujuh belas siswa yang mampu mencapai Kriteria Ketuntasan Minimal (KKM) $\geq 75$.

Untuk mengatasi hal salah satunya adalah dengan mengimplementasikan pembelajaran aktif. Pembelajaran aktif memuat banyak saran untuk membantu siswa memikirkan kembali pengalaman yang diperolehnya, yaitu aktivitas ketika pembelajaran (Silberman, 2013:9). Maka dari itu, pembelajaran berbasis aktivitas dapat digunakan dalam kegiatan pembelajaran untuk meningkatkan kualitas SDM nantinya. Rusman (2012:382) mengemukakan bahwa dalam pembelajaran berbasis aktivitas, siswa diberikan kesempatan yang terbuka untuk melakukan kreativitas dan mengembangkan potensinya melalui aktivitas secara langsung sesuai dengan minat dan keinginannya.

Pembelajaran berbasis aktivitas siswa (PBAS) merupakan suatu bentuk inovasi dalam memperbaiki kualitas proses belajar mengajar dengan tujuan membantu siswa agar dapat belajar mandiri dan kreatif, sehingga memperoleh pengetahuan, keterampilan, dan sikap yang dapat menunjang terbentuknya kepribadian yang mandiri (Sanjaya, 2012:181).

Pembelajaran berbasis aktivitas siswa menekankan pada aktivitas siswa secara optimal untuk memperoleh hasil belajar berupa perpaduan antara aspek kognitif, afektif, dan psikomotor secara seimbang. Siswa berperan sebagai subjek pendidikan sedangkan guru berperan sebagai penunjuk dan fasilitator dalam memanfaatkan sumber belajar.

\section{TINJAUAN PUSTAKA}

Susanto (2012:110) mengemukakan bahwa berpikir kreatif adalah menjadi sensitif terhadap permasalahan, kekurangan, dan celah di dalam pengetahuan, membawa informasi yang ada dari memori atau sumber eksternal, mendefinisikan kesulitan, mencari solusi, menduga, menciptakan alternatif dan mengujinya, menyempurnakan, dan akhirnya mengomunikasikan hasil-hasilnya. DePorter (2011:294) mengindikasikan orang-orang kreatif membuat lompatan yang memungkinkan mereka melihat apa yang belum pernah mereka alami sebelumnya. Merujuk pada pendapat dari para ahli di atas, maka keterampilan berpikir kreatif harus dikembangkan agar seseorang memiliki kepribadian kreatif yang akan sangat diperlukan ketika seseorang terebut menjalani kehidupan sekarang dan yang akan datang.

Sternberg (dalam Sudarma,2013:20) mengemukakan bahwa seseorang yang kreatif adalah seseorang yang dapat berpikir secara sistematis, artinya dapat melihat hubunganhubungan di mana orang lain tidak mampu melihatnya dan mempunyai kemampuan untuk menganalisis ide-idenya sendiri serta mengevaluasi nilai ataupun kualitas karya pribadinya, mampu menerjemahkan teori dan hal-hal yang abstrak ke dalam ide-ide praktis, sehingga individu mampu meyakinkan orang lain mengenai ide-ide yang akan dikerjakannya.

Berdasarkan beberapa teori yang diuraikan di atas, maka disimpulkan bahwa berpikir kreatif adalah suatu cara berpikir dimana seseorang mencoba menemukan hubunganhubungan baru untuk memperoleh jawaban baru terhadap pemecahan masalah melalui aktivitas mental yang terkait dengan kepekaan permasalahan tersebut, mempertimbangkan informasi baru dan ide-ide yang tidak biasa. Dalam berpikir kreatif, seseorang dituntut untuk dapat memperoleh lebih dari satu jawaban terhadap suatu persoalan.

Konsep merupakan kategori yang kita berikan pada stimulus yang ada di lingkungan kita. Konsep menyediakan skema terorganisasi untuk mengasimilasikan stimulus baru dan menentukan hubungan dan di dalam dan di antara kategori-kategori (Dahar, 2006:62).

Setiap konsep memiliki atribut yang melekat pada konsep tersebut. Seperti yang dinyatakan Rossser (dalam Dahar, 2006:63) bahwa konsep adalah suatu abstraksi yang mewakili satu kelas objek, kejadian, kegiatan, atau hubungan yang mempunyai atribut yang sama. Karena orang mengalami stimulus yang berbeda-beda, orang membentuk konsep sesuai dengan pengelompokan stimulus dengan cara tertentu atau berbeda. Soedjadi (dalam Ibrahim, 2012:2) mengemukakan bahwa konsep sebagai ide abstrak 
yang digunakan untuk mengadakan klasifikasi atau penggolongan yang pada umumnya dinyatakan dengan suatu istilah atau serangkaian kata. Dari pernyataan tersebut dapat disimpukan bahwa atribut konsep bersifat khusus. Menurut Ibrahim (2012:3), konsep didefinisikan sebagai kumpulan stimulus (fakta, benda, peristiwa, dll) yang memiliki ciri sama (atribut). Atribut adalah ciri esensial yang membedakan contoh konsep dari yang bukan contoh konsep.

Menurut Gagne, dkk. (dalam Ibrahim, 2012:9) menjelaskan bahwa penguasaan konsep adalah kemampuan yang memungkinkan seseorang dapat berbuat sesuatu. Berdasarkan pendapat tersebut, penguasaan konsep memiliki peranan yang penting dalam kehidupan manusia.

Berdasarkan beberapa definisi penguasaan konsep dari berbagai sumber diatas maka dapat disimpulkan bahwa penguasaan konsep adalah kemampuan seseorang dalam memahami makna pembelajaran baik itu berupa ide abstrak maupun gagasan logis dari fakta atau pengalaman yang dialami dan mampu menerapkan pemahaman makna pembelajaran tersebut dalam memecahkan masalah di kehidupan sehari-hari.

Pembelajaran berbasis aktivitas siswa adalah pendekatan pembelajaran yang menempatkan siswa sebagai subjek belajar dan kegiatan belajar bersifat modern. Pada pendekatan pembelajaran ini manajemen dan pengelolaannya ditentukan oleh siswa (Rusman, 2012:382). Menurut Sanjaya (2008:179), pembelajaran berbasis aktivitas siswa dapat dipandang sebagai suatu pendekatan dalam pembelajaran yang menekankan pada aktivitas siswa secara optimal untuk memperoleh hasil belajar berupa perpaduan antara aspek kognitif, afektif, dan psikomotor secara seimbang. Rusman (2012:391), pembelajaran berbasis aktivitas adalah pembelajaran yang memposisikan siswa sebagai subjek dalam kegiatan pembelajaran, sehingga akan memberikan konsekuensi keterlibatan siswa secara penuh mulai dari perencanaan pembelajaran, proses pembelajaran, sampai pada evaluasi pembelajaran.

Berdasarkan uraian dari berbagai sumber tentang pembelajaran berbasis aktivitas siswa di atas, maka dapat disimpulkan bahwa pembelajaran berbasis aktivitas siswa merupakan pendekatan pembelajaran yang menekankan situasi dan kondisi kegiatan belajar mengajar yang aktif namun terkontrol, di mana siswa sebagai subjek pembelajaran dan guru sebagai fasilitator, sehingga siswa mengalami pengalami pengalaman belajar yang bagus dan diharapkan siswa mampu mengembangkan aspek kognitif, afektif, dan psikomotor dalam dirinya secara seimbang dan memilki keterpaduan dari ketiga aspek tersebut.
Dalam pengajuan penelitian ini, peneliti menilik pada beberapa penelitian lain, diantaranya:

Simsek (2010) menyatakan bahwa "A teaching intervention was designed on the basis of IBL principles, which was put into practice in a 5th grade science class $(n=20)$. The findings indicated that IBL had a positive impact on students' conceptual understanding,' Maksudnya sebuah pengajaran dirancang atas dasar prinsip Inquiry-Based Learning (IBL) dan diimplementasikan ke dalam praktek pembelajaran sains di kelas $\mathrm{V}(\mathrm{n}=20)$. Temuan menunjukkan bahwa IBL memiliki dampak positif pada pemahaman konseptual siswa. Nantinya dalam penelitian ini, siswa dihadapkan pada berbagai masalah yang menuntut siswa untuk menemukan pemecahannya.

Karim (2012) menyatakan bahwa pembelajaran kooperatif tipe STAD menekankan pada aktivitas dan interaksi diantara siswa untuk saling memotivasi dan saling membantu dalam menguasai materi pelajaran sehingga kerjasama yang terjadi akan melibatkan semua anggota kelompok, disamping itu juga dari beberapa penelitian membuktikan bahwa penggunaan metode pembelajaran kooperatif tipe STAD dapat meningkatkan prestasi belajar siswa.

Supriyono (2014) menyatakan bahwa penerapan pembelajaran kooperatif tipe STAD dapat meningkatkan hasil belajar dan aktivitas belajar peserta didik. Hal ini dibuktikan dengan peningkatan rata-rata hasil belajar peserta didik.

Ersoy (2014) menyatakan bahwa "As a result of the study, an increase in the students' points for their creative thinking skills was observed at the end of the PBL process. In addition, it was determined that fluency, flexibility and originality, which are sub-dimensions of creative thinking skills, differed significantly". Maksudnya sebagai hasil dari penelitian, peningkatan poin siswa untuk keterampilan berpikir kreatif mereka dilatih pada akhir kegiatan pembelajaran Problem Based Learning (PBL). Selain itu, ditetapkan bahwa aspek kelancaran (fluency), fleksibilitas (flexibility), orisinalitas (originality), dan memerinci (elaboration) dapat membangun keterampilan berpikir kreatif secara signifikan.

Cetinkaya (2014) menyatakan bahwa "Results indicated that there was not a significant difference ( $p>.05)$ between pretest scores of both group. Concerning post-test and pre-test, a significant difference ( $p<.05)$ was found in favor of experimental group". Maksudnya hasil penelitian menunjukkan bahwa tidak ada perbedaan yang signifikan ( $\mathrm{p}$ $>0,05$ ) antara skor pretest dari kedua kelompok. Mengenai skor posttest dan pretest, terdapat perbedaan yang signifikan $(\mathrm{P}<0,05)$ dalam kelompok eksperimen. 
Aiamy (2012) menyatakan bahwa "The results show that, compared to traditional teaching method, synectics and brainstorming promote more creativity development, while the former has more significant effect". Maksudnya hasil penelitian menunjukkan bahwa, dibandingkan dengan metode pengajaran tradisional, metode synectics dan brainstorming lebih dapat melatih keterampilan berpikir kreatif secara signifikan.

Abdi (2012) menyatakan bahwa "Torrance's Creative Thinking Test was given to both groups as pretests and posttests. During the instruction, the experimental group received multiple intelligences based on learning science activities while the control group utilized traditionally designed science instruction by the same teacher over a period of 8 weeks. Results which were analyzed by covariance indicated that multiple intelligences- based instruction significantly stimulated students' creative thinking ability". Maksudnya uji berpikir kreatif Torrance dilakukan pada kelompok pra-tets dan post-tests. Selama penelitian, kelompok eksperimen menerima multiple intelligences, sedangkan kelompok kontrol menggunakan pembelajaran tradisional. Hasil yang dianalisis dengan kovarian menunjukkan bahwa kelompok eksperimen yang menerima multiple intelligences secara signifikan dapat melatih keterampilan berpikir kreatif.

Tirtawati (2014) menyatakan bahwa (1) terdapat perbedaan keterampilan berpikir kreatif dan hasil belajar biologi antara siswa yang dibelajarkan dengan pembelajaran kuantum dan peta pikiran dengan siswa yang dibelajarkan dengan model pembelajaran langsung, (2) terdapat perbedaan keterampilan berpikir kreatif antara siswa yang dibelajarkan dengan pembelajaran kuantum dan peta pikiran dengan siswa yang dibelajarkan dengan model pembelajaran langsung, dan (3) terdapat perbedaan hasil belajar biologi antara siswa yang dibelajarkan dengan pembelajaran kuantum dan peta pikiran dengan siswa yang dibelajarkan dengan model pembelajaran langsung.

Izzati (2014) menyatakan bahwa penerapan model pembelajaran berbasis proyek berpengaruh secara signifikan terhadap kemampuan berpikir kreatif mahasiswa.

Arnyana (2006) menyatakan bahwa kelompok siswa yang belajar dengan strategi kooperarif GI, PBL, dan Inkuiri, memiliki kemampuan berpikir kreatif lebih baik dibandingkan dengan kelompok siswa yang diajarkan dengan model DI.

Kusumaningrum (2016) menyatakan bahwa perangkat pembelajaran biologi dengan model PJBL yang efektif untuk untuk meningkatkan keterampilan proses sains dan kreativitas siswa pada aspek berpikir kreatif siswa.
Rohana (2016) menyatakan bahwa pembelajaran berbasis proyek dapat meningkatkan kreativitas siswa lebih tinggi secara signifikan dibandingkan dengan kelas ekspositori.

Budianto (2014) menyatakan bahwa kemampuan berpikir kreatif siswa yang mendapat pendekatan PBL lebih baik daripada siswa yang mendapat pembelajaran konvensional.

Busyairi (2015) menyatakan bahwa penerapan pembelajaran CPS berbasis eksperimen secara signifikan dapat lebih meningkatkan kemampuan kognitif dan keterampilan berpikir kreatif dalam pemecahan masalah siswa dibanding penerapan pembelajaran konvensional

Aydin (2014) menyatakan bahwa "Problem Based Learning Approach (PBLA) is an effective means for teaching mathematical concepts which students generally enjoy working on the real world problems". Maksudnya Problem Based Learning Approach (PBLA) adalah cara yang efektif untuk mengajarkan konsep-konsep sains yang umumnya dapat ditemui pada kehidupan sehari-hari.

Hadi (2013) menyatakan bahwa (1) ada pengaruh strategi PBL terhadap kemampuan berpikir kritis biologi siswa SMA Negeri di Kota Malang, dan (2) ada pengaruh strategi PBL terhadap pemahaman konsep biologi siswa SMA Negeri di Kota Malang.

Rahmawati (2013) menyatakan bahwa terdapat perbedaan pemahaman konsep antara siswa yang melaksanakan pembelajaran dengan metode mind mapping dengan siswa yang menggunakan metode ceramah dan presentasi.

Wadiadnyana (2014) menyatakan bahwa (1) terdapat perbedaan pemahaman konsep IPA dan sikap ilmiah antara siswa yang belajar menggunakan model discovery learning dengan siswa yang belajar menggunakan model pengajaran langsung $(F=7,791 ; p<0,05)$, (2) terdapat perbedaan pemahaman konsep IPA secara signifikan antara siswa yang belajar menggunakan model discovery learning dengan siswa yang belajar menggunakan model pengajaran langsung $(F=7,774 ; p<0,05)$, dan (3) terdapat perbedaan sikap ilmiah secara signifikan antara siswa yang belajar menggunakan model discovery learning dengan siswa yang belajar menggunakan model pengajaran langsung $(\mathrm{F}=$ 11,013; $\mathrm{p}<0,05)$.

Kurniati (2015) menyatakan bahwa terdapat perbedaan pemahaman konsep dan kemampuan aplikasi sains yang signifikan antara kelompok yang menggunakan Model Siklus Belajar 5E dibanding kelas kontrol.

Berdasarkan beberapa jurnal dan artikel ilmiah diatas, secara garis besar dapat ditarik kesimpulan bahwa pembelajaran yang bersifat student center memiliki tingkat 
keefektifan yang lebih tinggi jika dibandingkan dengan pembelajaran yang bersifat teacher center, utamanya dalam hal meningkatkan keterampilan berpikir kreatif dan penguasaan konsep.

\section{METODE}

Penelitian ini merupakan penelitian eksperimen semu atau quasi experiment yang dilakukan untuk mengetahui ada tidaknya perbedaan antara keterampilan berpikir kreatif dan penguasaan konsep siswa yang mengimplementasikan pendekatan pembelajaran berbasis aktivitas siswa dengan keterampilan berpikir kreatif dan penguasaan konsep siswa yang mengimplementasikan pendekatan pembelajaran bukan berbasis aktivitas siswa.

Peneliti akan mengujicobakan penelitiannya ke dalam kelas kontrol dan kelas eksperimen. Pada kelas kontrol akan diimplementasikan pendekatan pembelajaran bukan berbasis aktivitas siswa, sedangkan pada kelas eksperimen akan diimplementasikan pendekatan pembelajaran berbasis aktivitas siswa.

Waktu penelitian dilaksanakan pada tahun ajaran 2016/2017. Tempat penelitian di SDN Babat Jerawat II Surabaya dan SDN Rangkah VII Surabaya dengan pertimbangan: (1) sekolah bersifat terbuka dan mau menerima upaya inovasi terhadap pendidikan, (2) kesediaan dari pihak sekolah untuk bekerjasama dalam kegiatan penelitian, serta (3) memiliki kelas paralel sehingga memudahkan untuk pengelompokan kelas kontrol dan kelas eksperimen.

Menurut Sugiono (2011:215), populasi diartikan sebagai wilayah generalisasi yang terdiri atas objek atau subjek yang mempunyai kualitas dan karakteristik tertentu yang ditetapkan oleh peneliti untuk dipelajari dan kemudian ditarik simpulannya. Berdasarkan paparan tersebut, populasi dalam penelitian ini adalah seluruh siswa kelas V SDN Babat Jerawat II dan SDN Rangkah VII Surabaya tahun ajaran 2016/2017.

Menurut Sugiono (2011:215), sampel merupakan sebagian dari populasi itu sendiri. Dengan demikian, sampel dalam penelitian ini merupakan bagian dari siswa kelas $\mathrm{V}$ SDN Babat Jerawat II Surabaya dan siswa kelas V SDN Rangkah VII Surabaya tahun ajaran 2016/2017, dengan ketentuan tiga puluh siswa untuk masuk kelas kontrol dan tiga puluh siswa untuk masuk kelas eksperimen.

Adapun teknik pengambilan sampel dalam penelitian ini menggunakan teknik cluster sampling. Menurut Sugiono (2011:215), teknik cluster sampling digunakan untuk menentukan sampel bila obyek yang akan diteliti atau sumber data luas. Jumlah siswa kelas V SDN Babat Jerawat II berjumlah delapan puluh siswa yang terbagi dalam dua kelas dan siswa kelas V SDN Rangkah VII berjumlah delapan puluh siswa yang juga terbagi dalam dua kelas, adapun sampel yang akan diambil berjumlah enam puluh siswa (tiga puluh siswa kelompok kontrol dan 30 siswa kelompok eksperimen) dari masing-masing sekolah yang pengambilannya dilakukan secara random.

Rancangan penelitian yang digunakan adalah Pretest-Posttest Control Group Design (Sugiyono, 2013:112) dengan pola sebagai berikut.

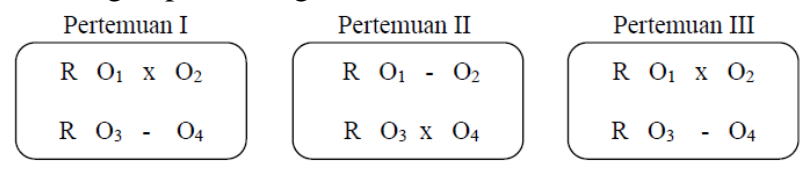

$$
\begin{array}{llll}
\mathrm{R} & \mathrm{O}_{1} & - & \mathrm{O}_{2} \\
\mathrm{R} & \mathrm{O}_{3} & \mathrm{x} & \mathrm{O}_{4}
\end{array} \quad \begin{array}{cccc}
\mathrm{R} & \mathrm{O}_{1} & \mathrm{x} & \mathrm{O}_{2} \\
\mathrm{R} & \mathrm{O}_{3} & - & \mathrm{O}_{4}
\end{array}
$$

Pada desain ini terdapat dua kelompok yang dipilih secara random, kemudian diberi pretest untuk mengetahui keadaan awal dan posttest untuk mengetahui data penelitian setelah pembelajaran.

Instrumen pengamatan pelaksanaan pembelajaran digunakan untuk memperoleh data kemampuan guru dalam melaksanakan pembelajaran. Pengamatan dilakukan dua orang pengamat dengan mengisi kolom-kolom yang tersedia dengan memberi tanda ceklist $(\sqrt{ })$ pada lembar pengamatan. Penilaian terdiri dari 5 kategori, yaitu tidak baik (skor 1), kurang baik (skor 2), cukup baik (skor 3), baik (skor 4), dan baik sekali (skor 5).

Instrumen pengamatan aktivitas siswa digunakan untuk merekam aktivitas siswa selama kegiatan pembelajaran. Pengamatan dilakukan oleh dua orang pengamat dengan mengisi kolom-kolom yang tersedia pada lembar pengamatan. Aspek-aspek pengamatan meliputi: Perhatian terhadap penjelasan guru, kerjasama dalam kelompok, bertanya apabila tidak mengerti, menjawab pertanyaan dalam kelompok, mengemukakan pendapat, mendengarkan dengan baik, dan saling membantu dalam menyelesaikan masalah.

Pengumpulan data menggunakan instrumen pengamatan pelaksanaan pembelajaran (aktivitas guru) dan pengamatan aktivitas siswa dilakukan dengan teknik pengumpulan data observasi. Observasi merupakan teknik pengumpulan data yang dilakukan dengan jalan pengamatan dan pencatatan secara sistematis, logis, objektif, dan rasional mengenai berbagai fenomena, baik dalam situasi yang sebenarnya maupun daam situasi buatan untuk mencapai tujuan tertentu. (Arifin, 2011:231).

Lembar catatan lapangan berisi rangkuman seluruh data lapangan yang terkumpul selama pelaksanaan pembelajaran dan digunakan untuk mencatat setiap kendala 
yang ditemui ketika implementasi pendekatan pembelajaran berbasis aktivitas siswa.

Instrumen penilaian keterampilan berpikir kreatif digunakan untuk mengukur tingkat kreativitas yang diperoleh siswa setelah mengikuti serangkaian kegiatan pembelajaran. Tingkat kreativitas siswa dilihat dari 4 kriteria, yaitu kelancaran (fluency), keluwesan (flexibility), kerincian (elaborasi), dan keaslian (orisinalitas) (Torrance dalam Filsaime, 2008:21-23).

Instrumen penilaian penguasaan konsep siswa berupa lembar tes berbentuk uraian objektif berbasis taksonomi SOLO yang digunakan untuk mengukur tingkat penguasaan konsep siswa pada tema Organ Tubuh Manusia dan Hewan. Bigg dan Collis (1982) membuat klasifikasi respon nyata dari anak-anak yang dinamakan Taksonomi SOLO (The Structure of the Observed Learning Outcome).

Pemberian tes digunakan untuk mengetahui keterampilan berpikir kreatif (secara individu) dan penguasaan konsep (secara individu dan klasikal). Tes diberikan dalam dua tahap baik pada kelas eksperimen (pembelajaran berbasis aktivitas siswa) maupun kelas kontrol (bukan pembelajaran berbasis aktivitas siswa), yaitu pretest yang diberikan di awal pembelajaran dan posttest yang diberikan di akhir pembelajaran.

Sebelum tes keterampilan berpikir kreatif dan penguasaan konsep digunakan untuk mengambil data dalam penelitian, soal tes diujicobakan kepada siswa di luar sampel. Setelah itu dilakukan teknik analisis data, yang terdiri atas:

$$
r_{x y}=\frac{\text { Uji Validitas }}{\sqrt{\left[N \sum x^{2}-\left(\sum x\right)^{2}\right]\left[N \sum x^{2}-\left(\sum y\right)^{2}\right]}}
$$

Uji Reliabilitas

$$
\begin{gathered}
r_{I I}=\left(\frac{n}{n-1}\right)\left(1-\frac{\Sigma \sigma_{1}^{2}}{\sigma_{1}^{2}}\right) \\
\text { Pelaksanaan Pembelajaran } \\
\bar{X}=\frac{\sum x_{i}}{n} \\
\text { Aktivitas Siswa } \\
P=\frac{f}{N} X 100 \%
\end{gathered}
$$

\section{HASIL DAN PEMBAHASAN}

Hasil pengamatan yang dilakukan pada kegiatan pembelajaran pertemuan 1 sampai dengan pertemuan 5 memperoleh rata-rata 4,2 dengan kriteria pelaksanaan pembelajaran berada dalam kategori baik. Artinya, guru sebagai mediator dan fasilitator bagi siswa dalam pembelajaran berbasis aktivitas siswa berjalan dengan baik. Hasil pelaksanaan pembelajaran di atas sesuai dengan teori yang dikemukanan Sanjaya (dalam Rusman, 2012:395) bahwa dalam pembelajaran berbasis aktivitas siswa, aktivitas belajar diciptakan dan dikondisikan oleh guru sebagai mediator dan fasilitator belajar siswa.

Sementara itu, pelaksanaan pembelajaran bukan berbasis aktivitas siswa menunjukkan hasil pengamatan yang dilakukan pada kegiatan pembelajaran pertemuan 1 sampai dengan pertemuan 5 memperoleh rata-rata 4,2 dengan kriteria pelaksanaan pembelajaran berada dalam kategori baik. Guru telah melaksanakan pembelajaran sesuai dengan RPP pembelajaran bukan berbasis aktivitas siswa dengan maksimal.

Menurut Sanjaya (2008:183), kriteria penerapan pembelajaran berbasis aktivitas siswa salah satunya adalah keterlibatan siswa dalam proses pembelajaran, yaitu (1) adanya keterlibatan siswa baik secara fisik, mentalemosional, maupun intelektual; (2) siswa dapat belajar secara langsung (experimential learning); (3) adanya keinginan siswa untuk menciptakan iklim belajar yang kondusif; (4) keterlibatan siswa dalam mencari dan memanfaatkan sumber belajar yang tersedia yang dianggap relevan dengan tujuan pembelajaran; (5) adanya keterlibatan siswa dalam melakukan prakarsa, seperti menjawab dan mengajukan pertanyaan, berusaha memecahkan masalah yang diajukan atau timbul selama proses pembelajaran berlangsung; serta (6) terjadinya interaksi yang multi arah baik antara siswa dengan siswa atau siswa dengan guru. Efektivitas pembelajaran tidak akan terwujud jika aktivitas-aktivitas siswa yang diharapkan muncul dalam pembelajaran tidak terjadi. Dalam penelitian ini, aktivitas-aktivitas siswa yang sesuai dengan pendekatan pembelajaran berbasis aktivitas siswa telah terlaksana dengan sangat baik. Hasil pengamatan yang dilakukan pada aktivitas siswa pertemuan 1 sampai dengan pertemuan 5 memperoleh persentase $83 \%$ atau $83 \%$ siswa telah melakukan aktivitas sesuai dengan kegiatan yang telah direncanakan. Adapun kriteria aktivitas siswa berada dalam kategori sangat baik. Sanjaya (2008:183) mengemukakan bahwa kriteria penerapan pembelajaran berbasis aktivitas siswa salah satunya adalah keterlibatan siswa dalam proses pembelajaran.

Sementara itu, aktivitas siswa pada pembelajaran bukan berbasis aktivitas siswa menunjukkan bahwa hasil pengamatan aktivitas siswa dari pertemuan 1 sampai dengan pertemuan 5 memperoleh persentase $31,7 \%$ atau hanya $31,7 \%$ siswa yang melakukan aktivitas sesuai dengan kegiatan yang telah direncanakan. Adapun kriteria aktivitas siswa berada dalam kategori kurang. Wajar mengingat 
pendekatan pembelajaran bukan berbasis aktivitas siswa lebih orientasi (berpusat) pada guru sebagai sumber informasi dengan cara guru menjelaskan materi pelajaran, sedangkan siswa hanya mendengarkan penjelasan guru.

Hasil pengujian tes keterampilan berpikir kreatif diperoleh hasil signifikansi sebesar 0,000. Dengan demikian demikian nilai nilai signifikansi tersebut lebih kecil dari derajat kesalahan 0,05 $(0,000<0,05)$.

Tabel 1. Uji T Posttest Keterampilan Berpikir Kreatif

\begin{tabular}{|c|c|c|c|c|c|c|c|c|c|c|}
\hline \multicolumn{11}{|c|}{ Independent Samples Test } \\
\hline & & \multicolumn{4}{|c|}{$\begin{array}{l}\text { Levene's Test } \\
\text { for Equality } \\
\text { of Variances }\end{array}$} & \multicolumn{3}{|c|}{ t-test for Equality of Means } & \multirow{2}{*}{\multicolumn{2}{|c|}{$\begin{array}{l}95 \% \text { Confidence } \\
\text { Interval of the } \\
\text { Difference }\end{array}$}} \\
\hline & & & & & & & & & & \\
\hline & & $\mathrm{F}$ & Sig. & t & df & (2-tailed) & Difference & Difference & Lower & Upper \\
\hline \multirow[t]{2}{*}{ Nilai } & $\begin{array}{l}\text { Equal variances } \\
\text { assumed }\end{array}$ & 25.862 & .000 & 14.066 & 118 & .000 & 17.833 & 1.268 & 15.323 & 20.344 \\
\hline & $\begin{array}{l}\text { Equal variances not } \\
\text { assumed }\end{array}$ & & & 14.066 & 88.437 & .000 & 17.833 & 1.268 & 15.314 & +20.353 \\
\hline
\end{tabular}

Berdasar hasil tersebut, menunjukkan terdapat perbedaan signifikan antara keterampilan berpikir pada kelompok kontrol (pendekatan pembelajaran bukan berbasis aktivitas siswa) dan kelompok eksperimen (pendekatan pembelajaran berbasis aktivitas siswa).

Keterampilan berpikir kreatif yang ditunjukkan dalam penelitian ini, memperlihatkan setelah mengikuti pembelajaran berbasis aktivitas siswa, aspek kelancaran (fluecy) memperoleh skor rata-rata 3,8 dari skor maksimal 4, fleksibilitas (flexibility) memperoleh skor rata-rata 3,6 dari skor maksimal 4, orisinalitas (originality) memperoleh skor rata-rata 3 dari skor maksimal 4, dan elaborasi (elaboration) memperoleh skor rata-rata 3,7 dari skor maksimal 4. Sementara itu, apabila dilihat dari segi isi, sebagian besar menceritakan pengalaman sehari hari yang terkait dengan materi pembelajaran dan sebagian yang lainnya merangkum kembali materi yang telah dipelajari. Demikian juga mengenai bentuk karangan, sebagian besar siswa mengerjakannya dalam bentuk karangan narasi dan ada pula yang mengaplikasikannya materi yang telah dipelajari sebelumnya ke dalam bentuk karangan dialog.

Hasil pengujian tes penguasaan konsep diperoleh hasil signifikansi sebesar 0,020. Dengan demikian demikian nilai signifikansi tersebut lebih kecil dari derajat kesalahan $0,05(0,020<0,05)$.

Tabel 1 Uji T Posttest Penguasaan Konsep

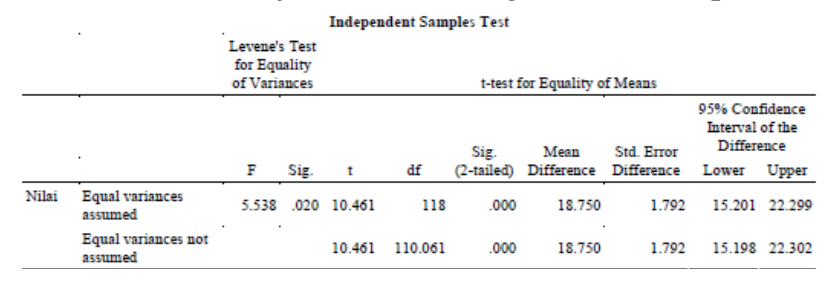

Berdasar hasil tersebut, menunjukkan terdapat perbedaan signifikan antara penguasaan konsep pada kelompok kontrol (pendekatan pembelajaran bukan berbasis aktivitas siswa) dan kelompok eksperimen (pendekatan pembelajaran berbasis aktivitas siswa).

Hasil penguasaan konsep yang dapat diketahui dalam penelitan ini, siswa mendapatkan nilai rata-rata 92,27 dari nilai maksimal 100 setelah mengikuti pembelajaran berbasis aktivitas siswa (kelompok eksperimen). Sementara itu pada kelompok kontrol (implementasi pembelajaran bukan berbasis aktivitas siswa) memperoleh nilai rata-rata penguasaan konsep sebesar 73,47, atau dapat dikatakan hasil tersebut masih berada dibawah Kriteria Ketuntasan Minimal $(\mathrm{KKM}) \geq 75$.

Berdasarkan hasil pengamatan pelaksanaan pembelajaran, aktivitas siswa, dan uji hipotesis keterampilan berpikir kreatif dan penguasaan konsep dapat ditarik sebuah simpulan bahwasannya jika pelaksanaan pembelajaran dan aktivitas siswa dapat terlaksana dengan baik, maka akan berbanding lurus dengan hasil keterampilan berpikir kreatif dan penguasaan konsep.

Setiap pembelajaran tentu mengalami kendala dalam pelaksanaannya, tidak terkecuali pada implementasi pendekatan pembelajaran berbasis aktivitas siswa (PBAS). Oleh karena itu diperlukan sikap guru yang profesional dalam membimbing dan memfasilitasi siswa dalam kegiatan belajarnya. Dengan dukungan sarana prasarana belajar yang memadai dan lingkungan belajar yang mendukung pengimplementasian pendekatan pembelajaran berbasis aktivitas siswa.

\section{SIMPULAN DAN SARAN}

Pelaksanaan pembelajaran pada implementasi pendekatan pembelajaran berbasis aktivitas siswa dan implementasi pendekatan pembelajaran bukan berbasis aktivitas siswa sama-sama terlaksana dengan baik, dikarenakan guru dalam mengajar sesuai dengan RPP yang telah dirancang sebelumnya (RPP PBAS dan RPP bukan PBAS). Dipihak lain aktivitas siswa pada saat implementasi pendekatan pembelajaran berbasis aktivitas siswa masuk dalam kategori baik dikarenakan pada pembelajaran PBAS menekankan kontribusi siswa pada kegiatan pembelajaran yang aktif, sedangkan aktivitas siswa pada saat implementasi pendekatan pembelajaran bukan berbasis aktivitas siswa masuk dalam kategori kurang dikarenakan dalam pendekatan pembelajaran bukan berbasis aktivitas siswa berpusat pada guru.

Terdapat perbedaan signifikan antara keterampilan berpikir kreatif pada kelompok kontrol (pendekatan pembelajaran bukan berbasis aktivitas siswa) dan kelompok 
eksperimen (pendekatan pembelajaran berbasis aktivitas siswa).

Terdapat perbedaan signifikan antara penguasaan konsep pada kelompok kontrol (pendekatan pembelajaran bukan berbasis aktivitas siswa) dan kelompok eksperimen (pendekatan pembelajaran berbasis aktivitas siswa).

Kendala-kendala dalam penelitian dapat diatasi dengan baik sehingga tidak mengganggu jalannya pembelajaran secara keseluruhan.

Berdasarakan hasil penelitian, perlu dilakukan inovasi dalam pelaksanaan kegiatan pembelajaran. Salah satunya untuk meningkatkan ketrampilan berpikir kreatif dan penguasaan konsep dapat digunakan pendekatan pembelajaran berbasis aktivitas siswa. Pembelajaran yang menempatkan siswa sebagai objek pembelajaran dapat melatih siswa untuk berpikir kreatif. Selain itu, dengan menempatkan siswa sebagai objek pembelajaran, siswa akan aktif mencari konsep-konsep yang membantu siswa dalam kegiatan pembelajaran.

Dalam penelitian ini hanya difokuskan pada pengaruh implementasi pendekatan pembelajaran berbasis aktivitas siswa terhadap keterampilan berpikir kreatif dan penguasaan konsep, hendaknya pada penelitian yang lebih lanjut faktor-faktor yang memengaruhi proses dan hasil belajar seperti faktor internal dan eksternal diamati dan diteliti.

\section{DAFTAR PUSTAKA}

Abdi, A. 2012. The effect Multiple intelligences-based instruction on Students' creative thinking ability at 5 th grade in primary school. Procedia - Social and Behavioral Sciences, 47(2012) 105-108

Ahmadi, Iif Khoiru. 2011. Mengembangkan Pembelajaran Aktif, Inovatif, Kreatif, Efektif, Menyenangkan, Gembira, dan Berbobot (PAIKEM GEMBROT). Jakarta: Prestasi Belajar.

Aiamy, M. 2014. The Effect of Synectics \& Brainstorming on 3rd Grade Students Development of Creative Thinking on Science. Procedia - Social and Behavioral Sciences, 47(2012) 610-613

Arifin, Zainal. 2011. Penelitian Pendidikan. Bandung: PT Remaja Rosdakarya.

Arikunto, Suharsini. 1989. Manajemen Penelitian. Jakarta: Departemen Pendidikan dan Kebudayaan.

Arnyana, I. B. P. 2006. Pengaruh Penerapan Strategi Pembelajaran Inovatif pada Pelajaran Biologi Terhadap Kemampuan Berpikir Kreatif Siswa SMA (Tesis master). Diperoleh dari http://undiksha.ac.id/ Aunurrahman. 2009. Belajar dan Pembelajaran. Bandung. Alfabeta.
Aydin, Y. 2014. The Effects of Problem Based Approach on Students Conceptual Understanding in a University Science Classroom. Procedia - Social and Behavioral Sciences, 152(2014) 704-707

Azwar, Saifuddin. 2012. Tes Prestasi. Yogyakarta: Pustaka Pelajar.

Budiyanto, A. M. 2014. Mengembangkan Kemampuan Berpikir Kretif Dan Kemandirian Belajar Siswa Sma Melalui Pembelajaran Berbasis Masalah (Tesis master). Diperoleh dari http://www.upi.edu/

Busyairi, A. 2015. Strategi Pembelajaran Creative Problem Solving (CPS) Berbasis Eksperimen Untuk Meningkatkan Kemampuan Kognitif Dan Keterampilan Berpikir Kreatif (Tesis master). Diperoleh dari http://www.upi.edu/

Cetinkaya, C. 2014. The Effect of Gifted Students Creative Problem Solving Program on Creative Thinking. Procedia - Social and Behavioral Sciences, 116(2014) 3722-3726

Dahar, Ratna Wilis. 2006. Teori-Teori Belajar \& Pembelajaran. Bandung: Gelora Aksara Pratama.

De Porter, Bobby. 2011. Quantum Learning. Bandung: Mizan Pustaka.

Ersoy, E. 2014. The Effects of Problem-Based Learning Method in Higher Education on Creative Thinking. Procedia - Social and Behavioral Sciences, 116(2014) 3494-3498

Fogarty, Robin. 1991. How To Integrated The Curricula. Illinois: IRI/Skylight Publishing, Inc.

Hadi A. M. 2014. Pengaruh Pembelajaran Problem Based Learning (PBL) Terhadap Kemampuan Berpikir Kritis dan Pemahaman Konsep Biologi Siswa SMA Negeri di Kota Malang (Tesis master). Diperoleh dari http://www.um.ac.id/

Hamalik, Oemar. 2001. Proses Belajar Mengajar. Bandung: PT Bumi Aksara.

Huda, Miftahul. 2011. Cooperative Learning. Yogyakarta: Pustaka Pelajar.

Husamah. 2013. Desain Pembelajaran Berbasis Pencapaian Kompetensi. Jakarta: Prestasi Pustaka.

Ibrahim, Muslimin. 2012. Konsep, Miskonsepsi, dan Cara Pembelajarannya. Surabaya: University Press.

Isjoni. 2010. Pembelajaran Kooperatif. Yogyakarta: Pustaka Pelajar.

Izzati, N. 2014. Pengaruh Penerapan Model Pembelajaran Berbasis Proyek Terhadap Kemampuan Berpikir Kreatif Mahasiswa (Tesis master). Diperoleh dari http://web.syekhnurjati.ac.id/ 
Julianto. 2010. Kajian Teori dan Implementasi Model Pembelajaran Terpadu Dalam Pembelajaran di Kelas. Surabaya: University Press.

Karim, A. S. 2012. Penerapan Model Pembelajaran Kooperatif Tipe Stad (Student-Teams-AchievmentDivisions) Untuk Meningkatkan Prestasi Belajar Dan Kerjasama Siswa (Tesis master). Diperoleh dari http://www.upi.edu/

Komalasari, Kokom. 2011. Pembelajaran Kontekstual. Bandung: Refika Aditama.

Kurniati, T. 2015. Penerapan Model Siklus Belajar 5e Terhadap Pemahaman Konsep Biologi Umum Dan Kemampuan Aplikasi Sains Mahasiswa Pendidikan Biologi (Tesis master). Diperoleh dari http://www.uinsgd.ac.id/

Kusumaningrum. 2016. Pengembangan Perangkat Pembelajaran Model Project Based Learning (PjBL) untuk Meningkatkan Keterampilan Proses Sains dan Kreativitas (Tesis master). Diperoleh dari https://www.uny.ac.id/

Lathifah, I. N. 2016. Pengembangan Perangkat Pembelajaran Integrated Science Berbasis Kearifan Lokal (Tesis master). Diperoleh dari https://www.uny.ac.id/

Nur, Mohamad. 2011. Model Pembelajaran Kooperatif. Surabaya: Pusat Sains dan Matematika Sekolah Unesa.

Poerwati, Loeloek Endah. 2013. Panduan Memahami Kurikulum 2013. Jakarta: Prestasi Pustaka.

Rahmawati, M. M. E. 2013. Pengaruh Mind Mapping dan Gaya Belajar Terhadap Pemahaman Konsep Siswa pada Pembelajaran IPA SMP Kelas VII (Tesis master). Diperoleh dari https://www.uny.ac.id/

Ratumanan, Tanwey Gerson dan Laurens Theresia. 2015. Penilaian Hasil Belajar pada Tingkat Satuan Pendidikan. Yogyakarta: Pensil Komunika.

Rohana, R. S. 2016. Project Based Learning untuk Meningkatkan Berpikir Kreatif Siswa SD pada Materi Makanan dan Kesehatan (Tesis master). Diperoleh dari http://www.upi.edu/

Rusman. 20112. Model-Model Pembelajaran. Jakarta: PT Raja Grafindo Perkasa.

Samatowa, Usman. Pembeajaran IPA di Sekolah Dasar. Jakarta: PT Indeks.

Sanjaya, Wina. 2012. Perencanaan dan Desain Sistem Pembelajaran. Jakarta: Prenada Media Group.

Silberman, Mel. 2013. Pembelajaran Aktif. Jakarta:PT Indeks.

Simsek, P. 2014. The Effects of Inquiry-Based Learning on Elementary Students Conceptual Understanding of
Matter, Scientific Process Skills and Science Attitudes. Procedia - Social and Behavioral Sciences, 2(2010) 1190-1194

Sudarma, Momon. 2013. Mengembangkan Keterampilan Berpikir Kreatif. Jakarta: Raja Grafindo Persada.

Sugiarto, Bambang. 2009. Mengajar Siswa Belajar. Surabaya: University Press.

Sugiyono. 2013. Metode Penelitian Pendidikan. Bandung: Alfabeta.

Supriyono. 2014. Upaya Meningkatkan Hasil Belajar Ipa Melalui Pembelajaran Kooperatif Tipe STAD Di Smpn 239 Jakarta (Tesis master). Diperoleh dari http://www.upi.edu/

Susanto, Ahmad. 2012. Teori Belajar dan Pembelajaran di Sekolah Dasar. Jakarta: Prenada Media Group.

Taniredja, Tukiran. 2011. Penelitian Kuantitatif (Sebuah Pengantar). Bandung: Alfabeta.

Tirtawati, N. L. R. 2014. Pengaruh Pembelajaran Kuantum (Quantum Learning) dan Peta Pikiran (Mind Mapping) Terhadap Keterampilan Berpikir Kreatif dan Hasil Belajar Biologi Siswa SMA (Tesis master). Diperoleh dari http://undiksha.ac.id/

Trianto. 2008. Mendesain Pembelajaran Kontekstual (Contextual Teaching and Learning) di Kelas. Jakarta: Cerdas Pustaka.

. 2010. Mengembangkan Model Pembelajaran Tematik. Jakarta: Prestasi Pustaka.

Wadiadnyana, I. W. 2014. Pengaruh Model Discovery Learning Terhadap Pemahaman Konsep IPA dan Sikap Ilmiah Siswa SMP (Tesis master). Diperoleh dari http://undiksha.ac.id/

Yaumi, Muhammad. 2012. Pembelajaran Berbasis Multiple Intelegences. Jakarta: Dian Rakyat.

Natawijaya, Rochman. (2005). Aktivitas Belajar. Jakarta: Depdiknas.

Puskur. (2001). Kurikulum Berbasis Kompetensi, Mata Pelajarann IPS Sekolah Dasar. Jakarta: PusKur Balitbang, Depdiknas.

Roesminingsih, MV. (2005). Teori dan Praktek Pendidikan. Surabaya: FIP UNESA

Sapriya. (2009). Pendidikan IPS Konsep dan Pembelajaran. Bandung: PT Remaja Rosdakarya.

Sugiyono. (2011). Metode Penelitian Pendidikan. Bandung: Alfabeta

Susanto, Ahmad. (2013). Teori Belajar \& Pembelajaran di Sekolah Dasar. Jakarta: PT. Kharisma Putra Utama. 